\title{
Malignant Transformation and Stromal Invasion from Normal Appearing Prostate Tissues: True or False?
}

\author{
Yan-gao Man \\ The Diagnostic and Translational Research Center \\ Henry Jackson Foundation, Gaithersburg \\ USA
}

\section{Introduction}

The human prostate epithelium, which is the histological origin of most prostate malignancies, is physically separated from the stroma by a layer of basal cells and the basement membrane. Basal cells are inter-connected by intercellular junctions and adhesion molecules, constituting a continuous sheet encircling luminal cells [1-2]. The basement membrane is composed of type IV collagen, laminins, and other molecules, forming a continuous lining surrounding and attaching to the basal cell layer [3-4] (Fig 1). The basement membrane and the basal cell layer are intermixed to form a dense fibrous capsule surrounding all epithelial cells. Due to these relationships, disruption of the basal cell layer and the basement membrane is a pre-requisite for tumor invasion or metastasis.

It is a commonly held belief that prostate carcinogenesis progresses sequentially from normal to hyperplasia, to prostatic intraepithelial neoplasia (PIN), and to invasive or metastatic lesions [5-8]. Progression from PIN to invasion is believed to be triggered by overproduction of proteolytic enzymes primarily by cancer cells, which cause degradation of the tumor capsule [9-10]. These theories are consistent with laboratory findings from cell cultures and animal models, whereas are hard to reconcile with a number of critical facts. First, previous studies revealed that some healthy men between 19 and 29 years old had a spectrum of proliferative lesions, including hyperplasia, PIN, and incipient adenocarcinoma [11-13]. Second, recent studies have detected a DNA phenotype identical to that of invasive prostate cancer in some "healthy" men, and also in normal prostate tissues adjacent to prostate cancer [14-17]. Third, a majority of PIN express high levels of proteolytic enzymes, but only $10-30 \%$ of untreated PIN progress to invasive lesions during patients' lifetime [1821]. Fourth, cancer of unknown primary site is one of the 10 most frequent cancers worldwide and the $4^{\text {th }}$ most common cause of cancer deaths [22-24].

Together, these facts argue that the linear model of carcinogenesis [5-8] and enzyme theory of tumor invasion [9-10] are not universally applicable to all prostate cancer cases. These facts also suggest that the past efforts to classify tumor progression and invasion purely based on the profiles of epithelial cells may have overlooked some essential factors. As over $90 \%$ of prostate cancer related mortality result from invasion related diseases, and the incidence of PIN could be up to $16.5 \%-25 \%$ in prostate biopsies [25-27], there is an urgent 
need to uncover the intrinsic mechanism of tumor invasion and to distinguish aggressive and indolent PIN for optimal or personalized treatment. Unfortunately, none of the current approaches could predict which PIN lesions will progress [28-31]. The only established approach to monitor PIN progression is repeat biopsy [28-31], which is costly and painful.

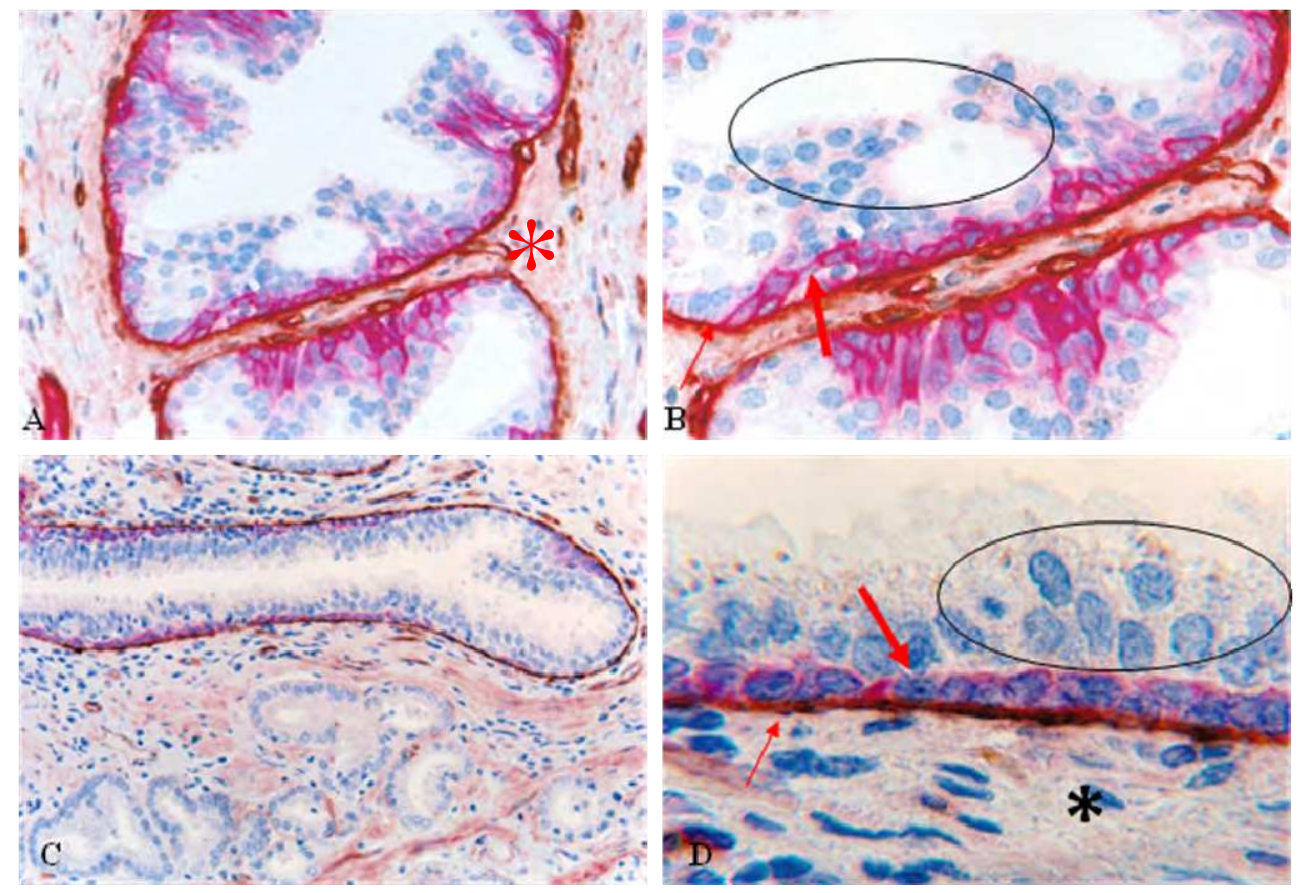

Fig. 1. Structural relationships among the epithelium (circles), basal cell layer (thick arrows), basement membrane (thin arrows), and stroma (asterisks). Human prostate tissue sections were double immunostained for collagen IV (brown) and cytokeratin 34ßE12 (red). A and C: 150X. B and D: a higher (500X) magnification of A and C.

Promoted by the fact that the basal cell layer is the sole source of tumor suppressor p63 and maspin [32-35], and that degradation of the basal cell layers is a pre-requisite for tumor invasion, our resent studies have attempted to identify early signs of basal cell degradation. Our initial study examined the physical integrity of the basal cell layers in 50 patients with co-existing pre-invasive and invasive prostate tumors. Of 2,047 ducts and acini examined, 197 were found to harbor focal disruptions (the absence of basal cells resulting in a gap greater than the combined size of at least 3 basal cells) in their basal cell layers. The frequency of focal basal cell layer disruptions (FBCLD) varied from none in 22 (44\%) cases to over $1 / 3$ of the ducts or acini with FBCLD in 17 (34\%) cases (Table 1) [36]. Of the 17 cases with a high frequency of FBCLD, 5 harbored large acinar or duct clusters that are morphologically normal in H\& E stained sections, but all harbored focal disruptions in the surrounding capsule in immunostained sections. As shown in Fig 2a, each of the 12 epithelial structures in one of such cases harbors FBCLD, but none of the 12 morphologically similar epithelial structures in Case B shows FBCLD. 
Malignant Transformation and Stromal Invasion

\begin{tabular}{|c|c|c|c|c|}
\hline Case number & No disruptions & $<\mathbf{3 0} \%$ disruptions & $\mathbf{2 3 0} \%$ disruptions & $\mathbf{p}$ \\
\hline 50 & $22(44 \%)$ & $11(22 \%)$ & $17(34 \%)$ & $<0.01$ \\
\hline
\end{tabular}

Table 1. Frequencies of focal basal cell layer disruptions among cases

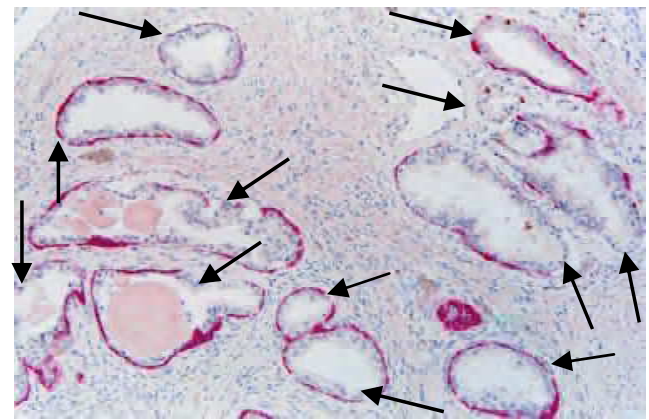

(a)

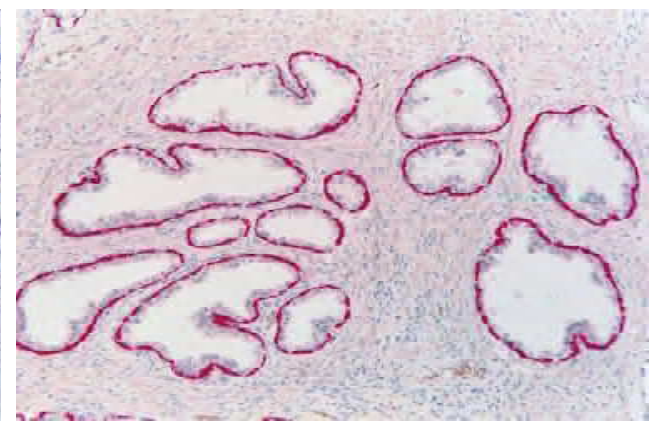

(b)

Fig. 2. Different frequencies of FBCLD among cases. Double immunostained for CK 34BE12 (red) and Ki-67 (brown). In Case A, all 12 epithelial structures show FBCLD (arrows), whereas in Case B, none shows FBCLD. 200X.

Compared to their non-disrupted counterpart, focally disrupted basal cell layers in these 17 cases displayed several unique alterations that were not or rarely seen in morphologically similar structures in other cases [36-44]:

A. significantly reduced expression of tumor suppressor p63: In sections double immunostained for p63 and CK 34ßE12, an average of $87 \%$ of the basal cells in nondisrupted layers expressed both molecules, while only $59 \%$ of the basal cells in focally disrupted layers showed p63 expression (Fig 3; Table 2).

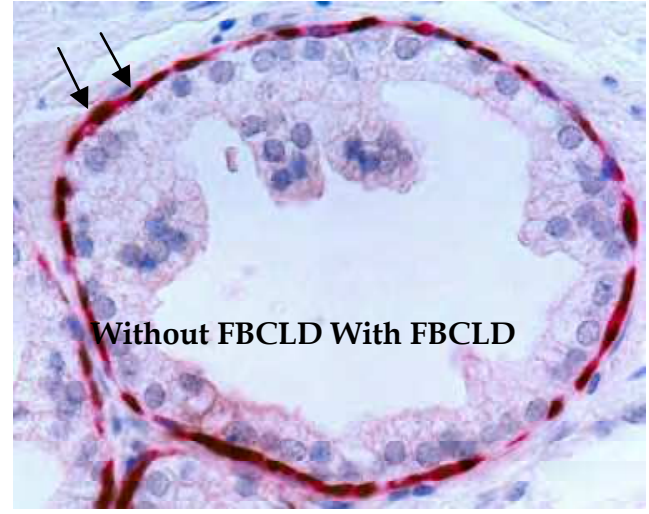

(a)

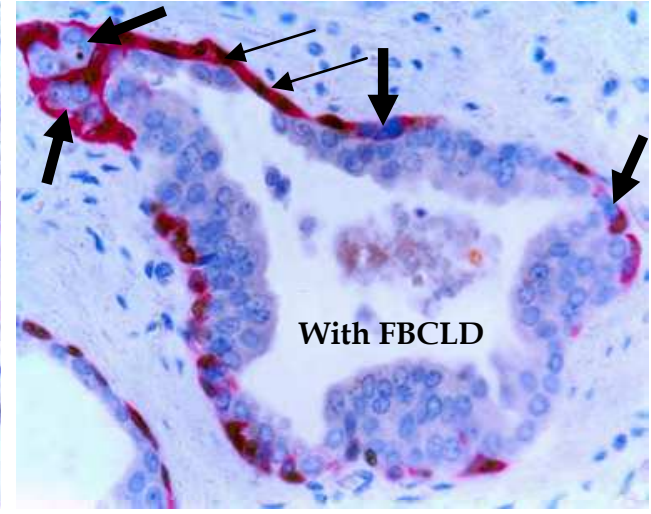

(b)

Fig. 3. Reduction of p63 expression in focally disrupted basal cell layers. Sections were double immunostained for CK 34ßE12 (red) and p63 (black). Thin and thick arrows identify cells with and without p63 expression, respectively. 400X. 


\begin{tabular}{|c|c|c|c|}
\hline Basal cell layer status & $\begin{array}{c}\text { Number of ducts or } \\
\text { acini }\end{array}$ & Percentage of p63 (+) cells & P \\
\hline With disruption & 197 & $59 \%$ & \multirow{2}{*}{$<0.01$} \\
\hline W/o disruption & 197 & $87 \%$ & \\
\hline
\end{tabular}

Table 2. p63 expression in basal cell layers with and without focal disruption

B. significantly reduced expression of proliferating cell nuclear antigen (PCNA): In sections double immunostained for PCNA and CK34 3 E12, an average of $74 \%$ of the normal basal cells showed PCNA expression, but only $51 \%$ of basal cells in disrupted basal layers showed PCNA expression (Fig. 4; Table 3).

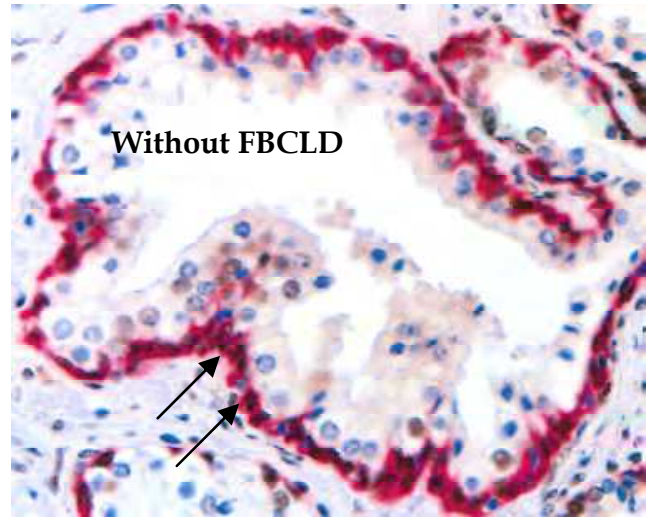

(a)

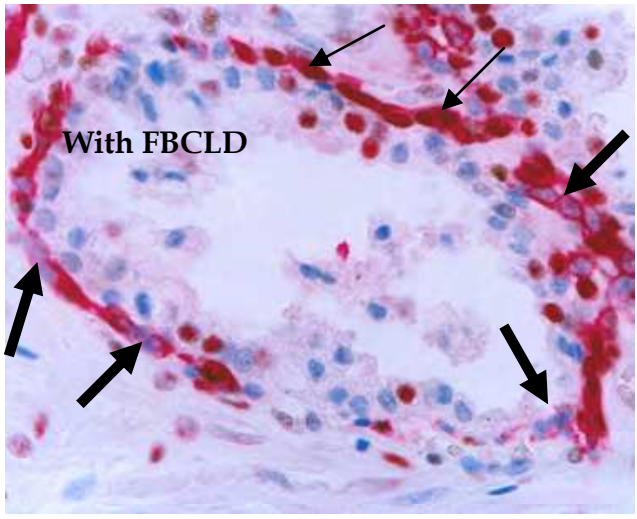

(b)

Fig. 4. Significantly reduced PCNA expression in basal cell layers with FBCLD. Double immunostained for CK34 $\beta$ E12 (red) and PCNA (black). Thin and thick arrows identify basal cells with and without PCNA expression, respectively. 400X

\begin{tabular}{|c|c|c|c|}
\hline Basal cell layer status & $\begin{array}{c}\text { Number of ducts or } \\
\text { acini }\end{array}$ & \% of PCNA (+) cells & P \\
\hline With disruption & 50 & $51 \%$ & $<0.01$ \\
\hline W/o disruption & 50 & $74 \%$ & $<$ \\
\hline
\end{tabular}

Table 3. PCNA expression in basal cell layers with and without focal disruption

C. significantly elevated apoptosis and degeneration: Of 78 epithelial structures with FBCLD examined, 59 (75.6\%) harbored apoptotic basal cells, compared to $9 \%(11.5 \%)$ in 78 similar structures with intact basal layers.

Under high magnification, basal cells near FBCLD often had cytological signs of degeneration, including nuclear swelling, shrinkage, fragmentation, or rod-like structures of fused basal cells (Fig. 5). 

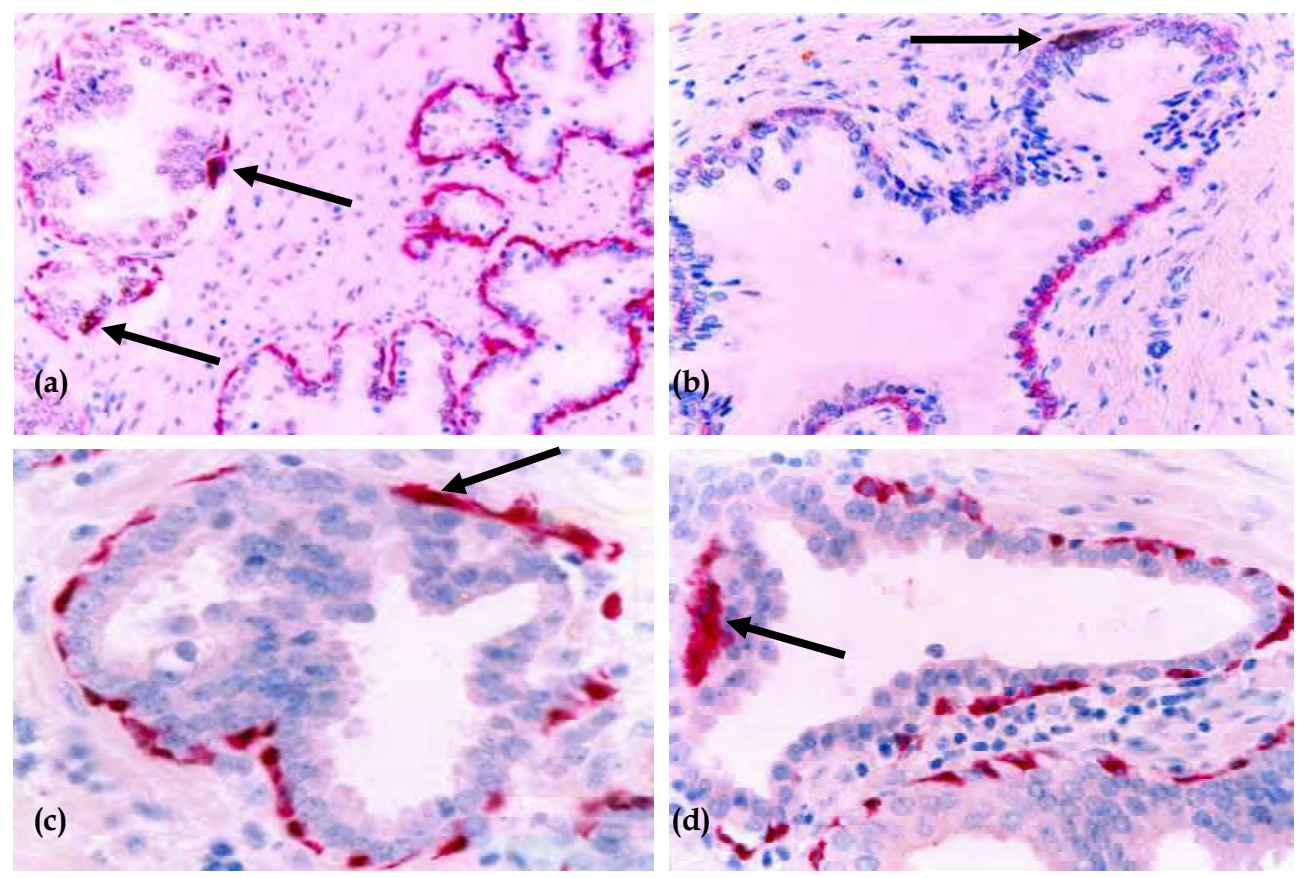

Fig. 5. Elevated apoptosis and degeneration in focally disrupted basal cell layers. Section was assessed for apoptosis (a-b) or CK34 $\beta E 12$ expression (c-d). Arrows identify apoptotic or degenerated basal cells arranged as rod-like structures. 300X.

D. significantly elevated leukocyte infiltration: In sections double immunostained for CK $34 \beta E 12$ and leukocyte common antigen (LCA), most structures with FBCLD showed leukocyte infiltration, but most structures with non-disrupted layers had no leukocyte infiltration (Table 4). Most leukocytes were located near FBCLD (Fig 6).

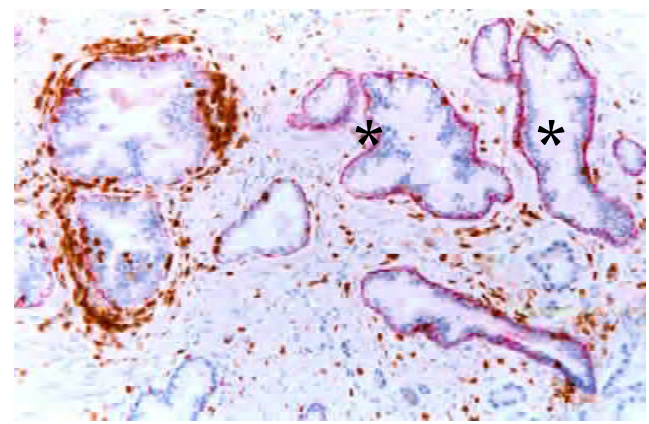

(a)

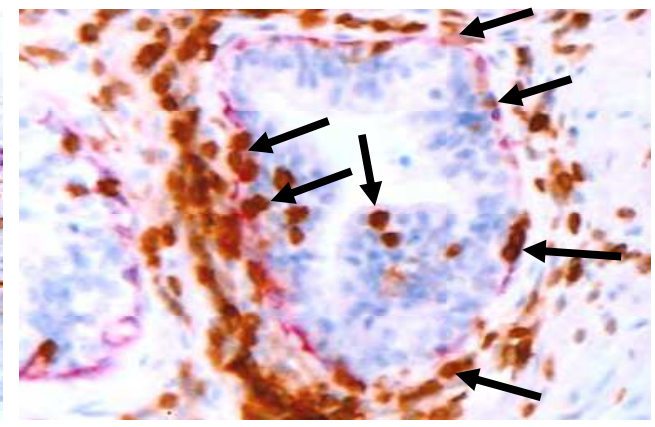

(b)

Fig. 6. FBCLD and infiltration of LCA=positive cells. Double immunostained for CK34ßE12 (red) and LCA (brown). Arrows identify infiltrates within the epithelium or near FBCLD. No leukocyte infiltration was seen in ducts with non-disrupted basal cell layers (asterisks). A; 100X. B: a higher (300X) magnification of A. 


\begin{tabular}{|c|c|c|c|}
\hline Basal cell layer status & $\begin{array}{c}\text { Number of ducts or } \\
\text { acini }\end{array}$ & $\begin{array}{c}\text { Number of leukocyte } \\
\text { infiltration }\end{array}$ & P \\
\hline With focal disruptions & 201 & $183(91.0 \%)$ & \\
\cline { 1 - 3 } $\begin{array}{c}\text { Without focal } \\
\text { disruptions }\end{array}$ & 201 & $67(33.3 \%)$ & $<0.01$ \\
\hline
\end{tabular}

Table 4. Leukocyte infiltration in epithelial structures with and without focal basal cell layer disruption

E. a total loss of the expression of all basal cell phenotypic markers: In addition to focal alterations, the entire basal cell layer in some epithelial structures of some cases showed degenerative changes. These basal cell layers were morphologically distinct, surrounding PIN or normal-appearing duct or acinar clusters (Fig 7). All the basal cells, however, lacked the expression of basal cell specific markers (Fig 7). Epithelial associated with these basal cell layers often showed malignant cytology, including enlarged nuclei and nucleoli.
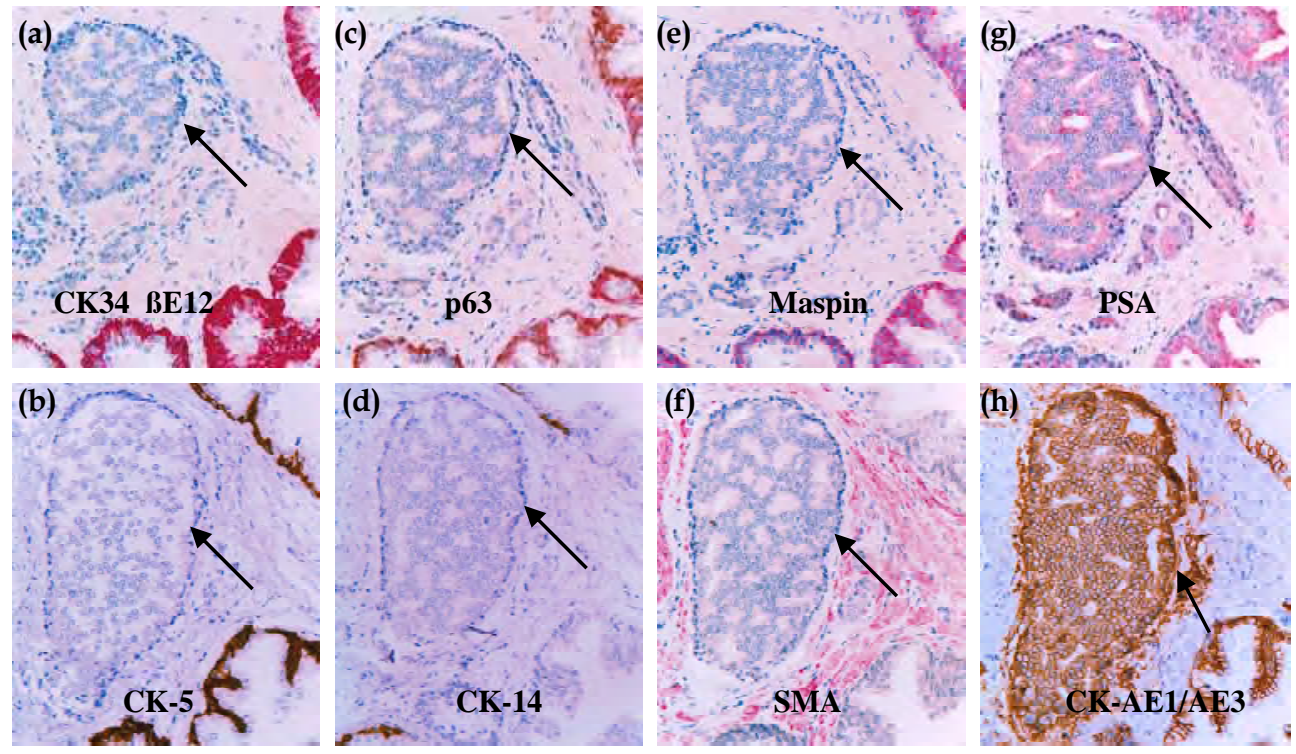

Fig. 7. Morphologically distinct basal cell layers lack expression of all basal cell specific markers. Immunostained for basal (a-e), stromal (f), and epithelial (g-h) cell markers. Arrows identify altered basal cell layers. 200X.

In addition, these basal cell layers were devoid of expression of PCNA, in contrast to normal basal cells and associated tumor cells, which were strongly positive for PCNA (Fig. 8). Epithelial structures with altered basal cell layers often had mast cell infiltration, which was not seen in structures with intact basal cell layers (Fig 8). 

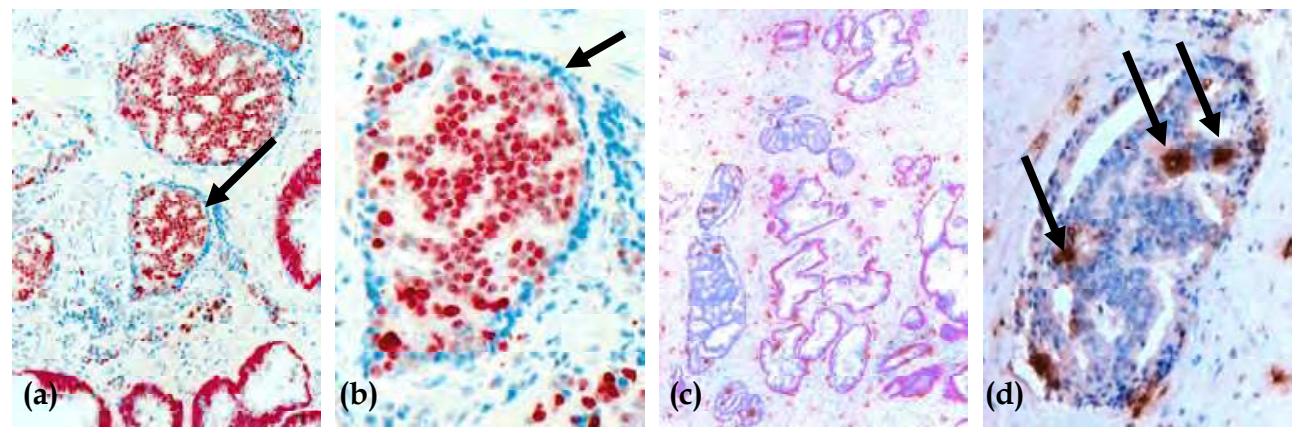

Fig. 8. PNA expression and mast cell infiltration in acini with altered basal cell layers. Double immunostained for CK34 $\beta$ E12 (red) and PCNA (brown) or mast cells (black). Arrows identify basal cells or mast cells. a \& c: 100X. b \& d: 400X.

Together, these findings suggest that focally disrupted basal cell layers are likely to be under degeneration. As the basal cell layer is the sole source of several tumor suppressors [29-32], degenerated basal cells are very likely to have impaired or reduced paracrine inhibitory functions on tumor cell growth and invasion. In contrast to degenerative alterations in basal cells, luminal cells overlying FBCLD showed several signs of proliferative alterations that were not seen in their adjacent counterparts distant from the disruptions:

A. significantly elevated proliferation: In section double immunostained for basal cell and proliferation markers, epithelial structures with FBCLD had a significantly higher proliferation index than their morphologically similar counterparts without FBCLD, and most proliferating cells were located at or near FBCLD (Fig.9; Table 5).

\begin{tabular}{|c|c|c|c|}
\hline Duct or acinar type & Total number & With proliferating cells & P \\
\hline With disruption & 78 & $47(62.5 \%)$ & \multirow{2}{*}{$<0.01$} \\
\hline W/o disruption & 78 & $8(10.2 \%)$ & \\
\hline
\end{tabular}

Table 5. Cell proliferation in epithelial structures with and without focal basal cell layer disruption
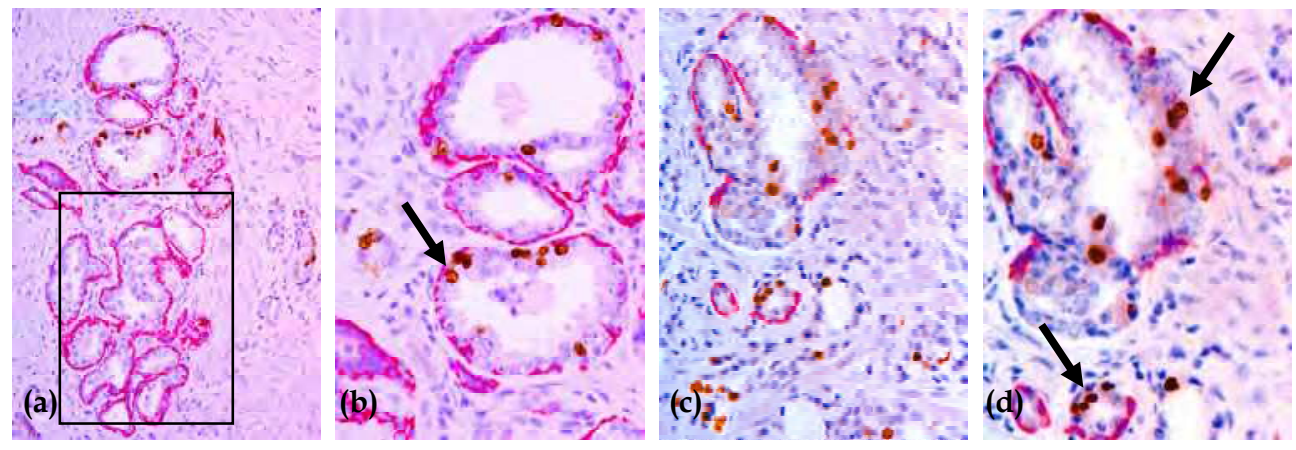

Fig. 9. Increased proliferation in ducts with FBCLD. Sections were double immunostained for CK $34 \beta E 12$ (red) and Ki-67 (brown). Arrows identify proliferating cell clusters. Note that in $a-b, K I-67$ positive cells are seen in ducts with FBCLD, but not in adjacent ducts without FBCLD (square). a \& c: 100X. b \& d: a higher (400X) magnification of a and c, respectively. 
B. significantly higher expression of malignancy- and tumor invasion-related molecules: Elevated expression of prostate specific antigen (PSA) and alpha-methylacyl-CoA racemase (AMACR), are seen in cells overlying FBCLD (Fig.10a \& b), and also in normal ducts lacked the expression of basal cell markers (Fig. 10c \& d). In contrast, cells within the same duct, and adjacent ducts with intact basal cell layers were negative (Fig 10).
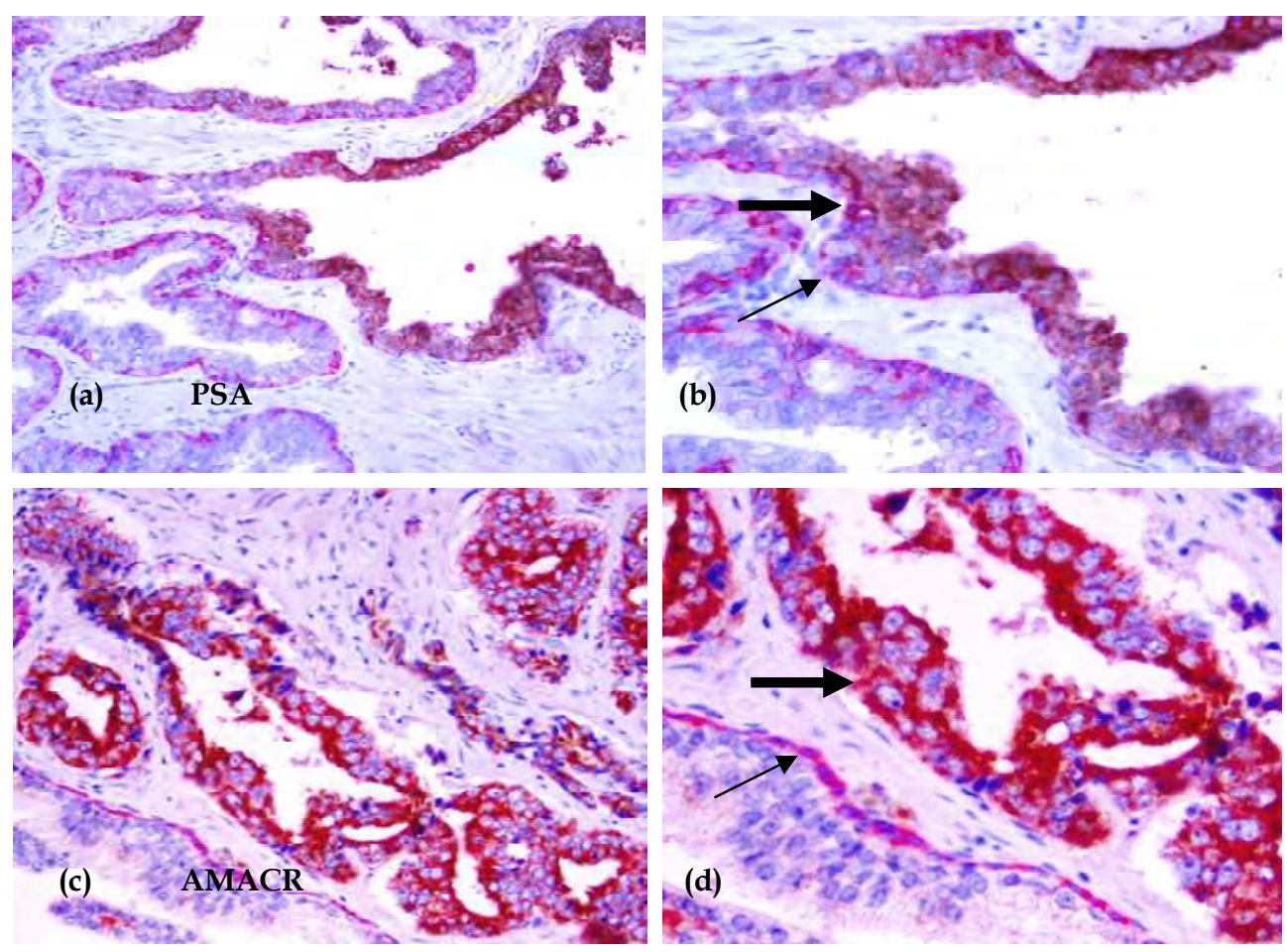

Fig. 10. PSA and AMACR expression in cells overlying FBCLD and ducts with altered basal cells. Double immunostained for CK34 $\beta$ E12 (red) and PSA or AMACR (brown). Thick arrows identify cells with AMACR or PSA expression. Thin arrows identify residual basal cells. a \& c: 100X. b \& d: a higher magnification (400X) of a \& c, respectively.

C. physical continuity with, and morphological resemblance to, invasive prostate cancer: A vast majority of these normal appearing acinar or duct clusters were immediately adjacent to, or blended with, invasive cancers. In some cases, cells overlying FBCLD had significantly enlarged nuclei and nucleoli, and were often in physical continuity with, or morphologically similar to, their adjacent invasive counterparts (Fig 11).

In some cases, multiple epithelial cell nests appeared to be "budding" from the same acinus or duct (Fig.12). These "budding" cells had a higher proliferation and were similar to adjacent invasive cancer cells. The only difference was that "budding" cells are often associated with residual basal cells (Fig 12, thin arrows). 


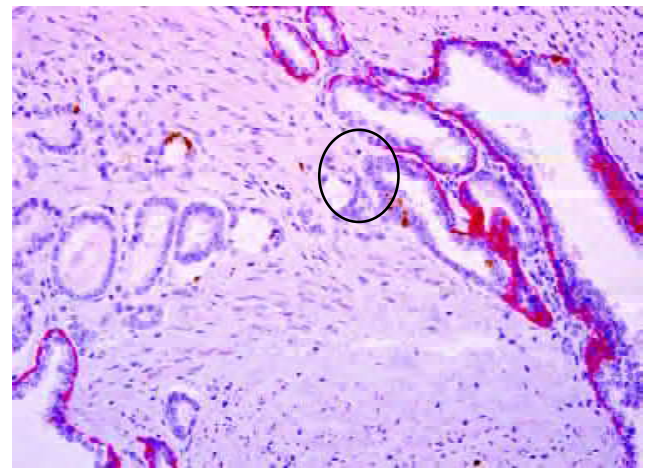

(a)

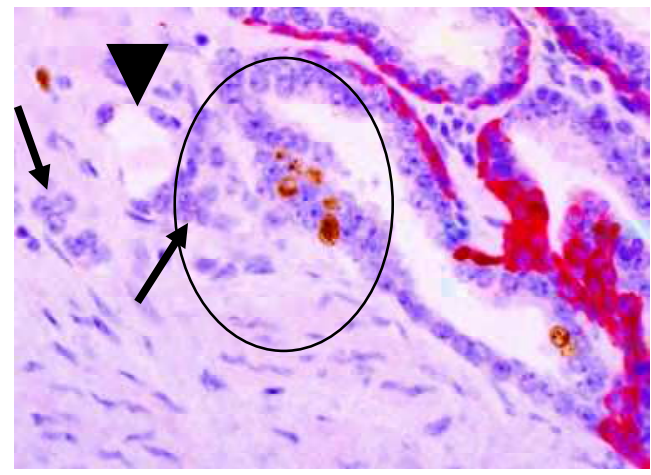

(b)

Fig. 11. Physical continuity with, and morphological resemblance to, invasive cancer. Double immunostained for CK 34ßE12 (red) and Ki-67 (brown). Circles identify proliferating cells overlying FBCLD. Note that cells overlying FBCLD are in direct continuity and similar to invasive cancer cells (arrows). Cells near FBCLD appear to invade a small and dilated vein (arrowhead). a: 100X. b: a higher (400X) magnification of a.
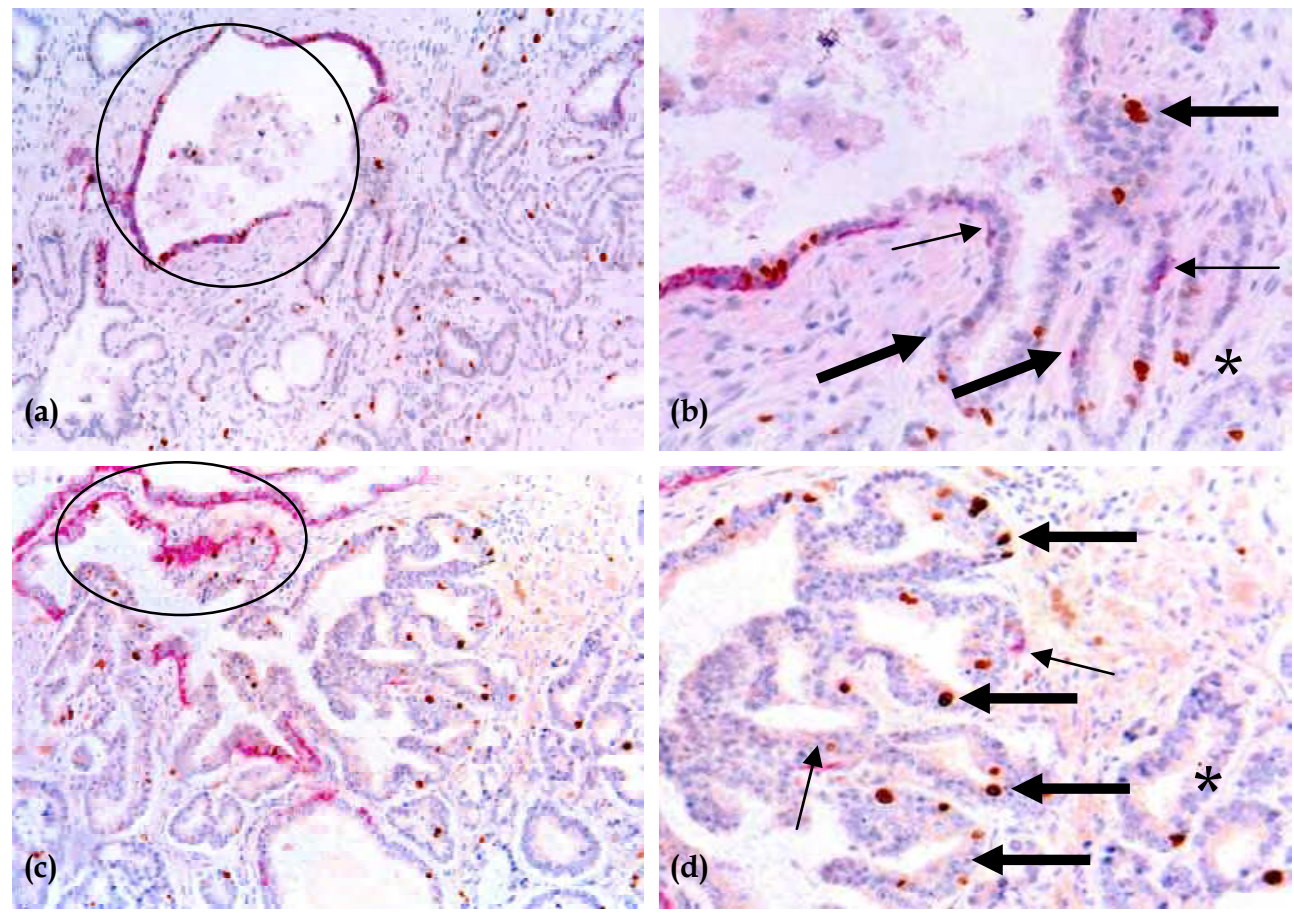

Fig. 12. Cell "budding" from normal epithelial structures. Double immunostained for CK34ßE12 (red) and Ki-67 (brown). Circles identify normal epithelial structures. Thick arrows identify "budding" cell clusters. Thin arrows identify residual basal cells. Asterisks identify invasive cancers. a \& c: 100X. b \& d: a higher (400X) magnification of a and c, respectively. 
D. Significantly higher expression of chromogranin A: In sections double immunostained for CK $34 \beta E 12$ and chromogranin A, a neuroendocrine differentiation-related marker correlating with tumor progression and the status of hormone refractoriness [45-47], chromogranin A positive cells were exclusively or preferentially seen in epithelial structures with FBCLD (Fig 13). Compared to morphologically similar counterparts, microdissected epithelial structures with chromogranin A-positive cell clusters had a more than 5- and 7fold lower expression of Micro-RNAs 146a and 146b-5p (miR-146a and miR-146b-5p; Fig 14), which have been documented to correlate with prostate tumor invasion and hormone refractoriness [38].
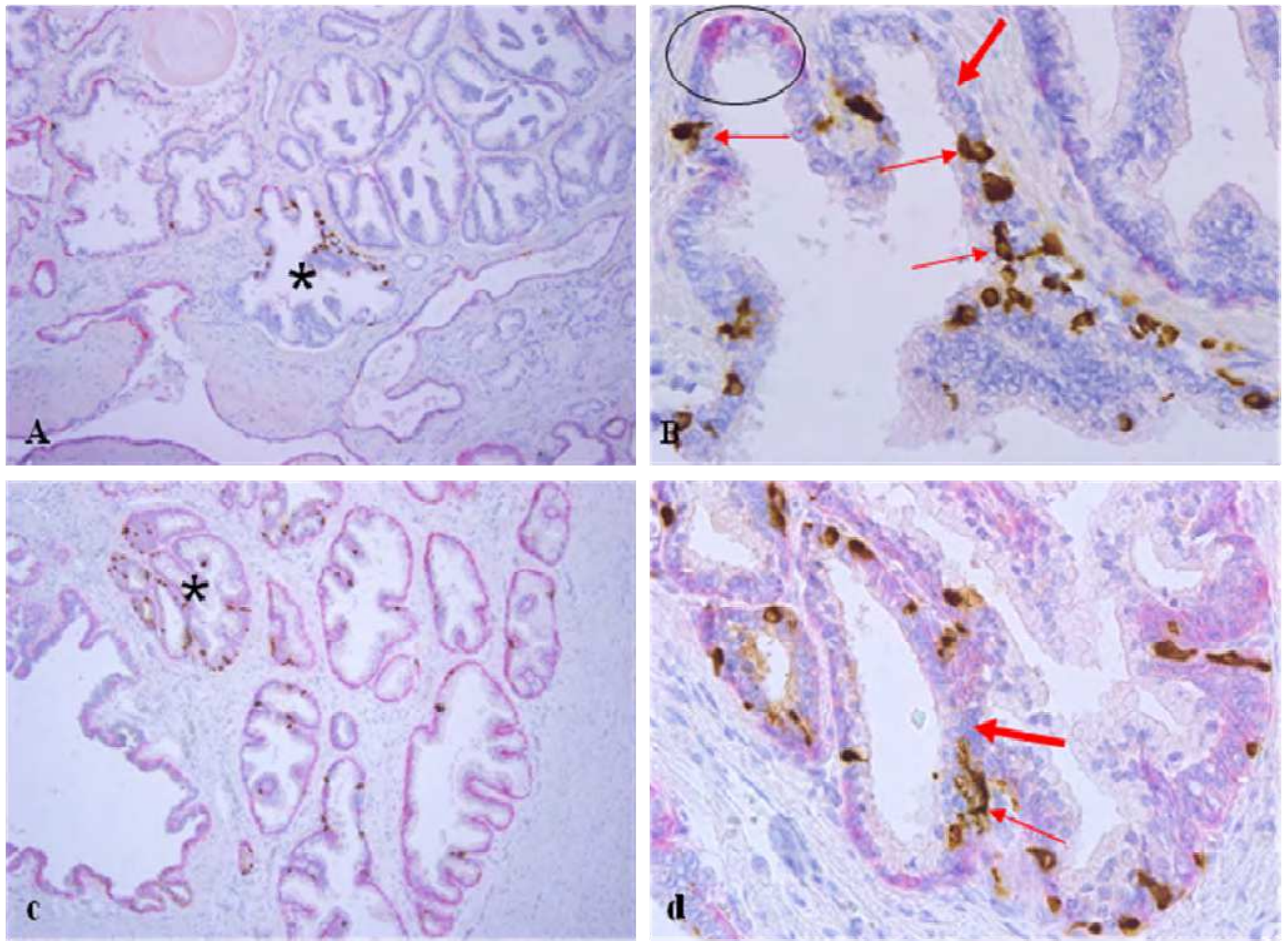

Fig. 13. Chromogranin A positive cells preferentially in epithelial structures with FBCLD. Double immunostained for CK $\beta$ E12 (red) and chromogranin A (black). Thick arrows identify FBCLD. Thin arrows identify chromogranin A-positive cells. Circle identifies residual basal cells. Asterisks identify epithelial structures with FBCLD. 
hsa-mir-146b-5p

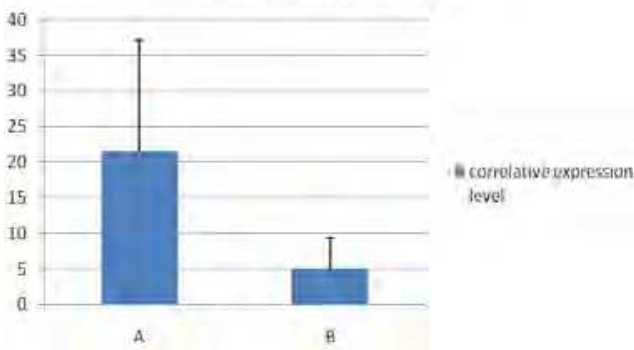

hsa-mir-146a

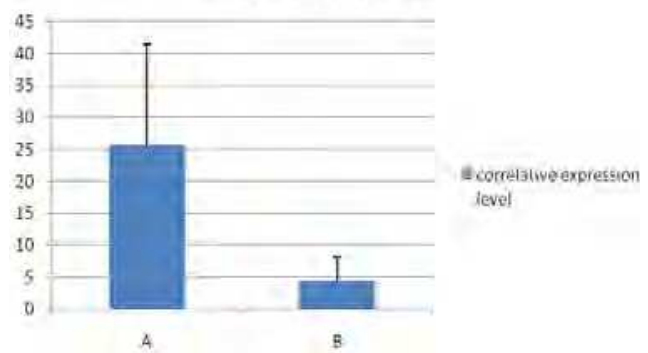

Fig. 14. Correlative expression levels of miR-146a and 146b-5p in microdissected epithelial structures with (B) and without chromogranin-A positive cell clusters (A).

E. significantly elevated expression of tumor invasion-related genes: Compared to their adjacent counterpart associated with the residual basal cell layer within the same duct, microdissected cell clusters overlying FBCLD consistently had significantly higher expression of cell proliferation, apoptosis, angiogenesis, immuno-response, and stem cell related genes [38] (Fig 15; Table 6).
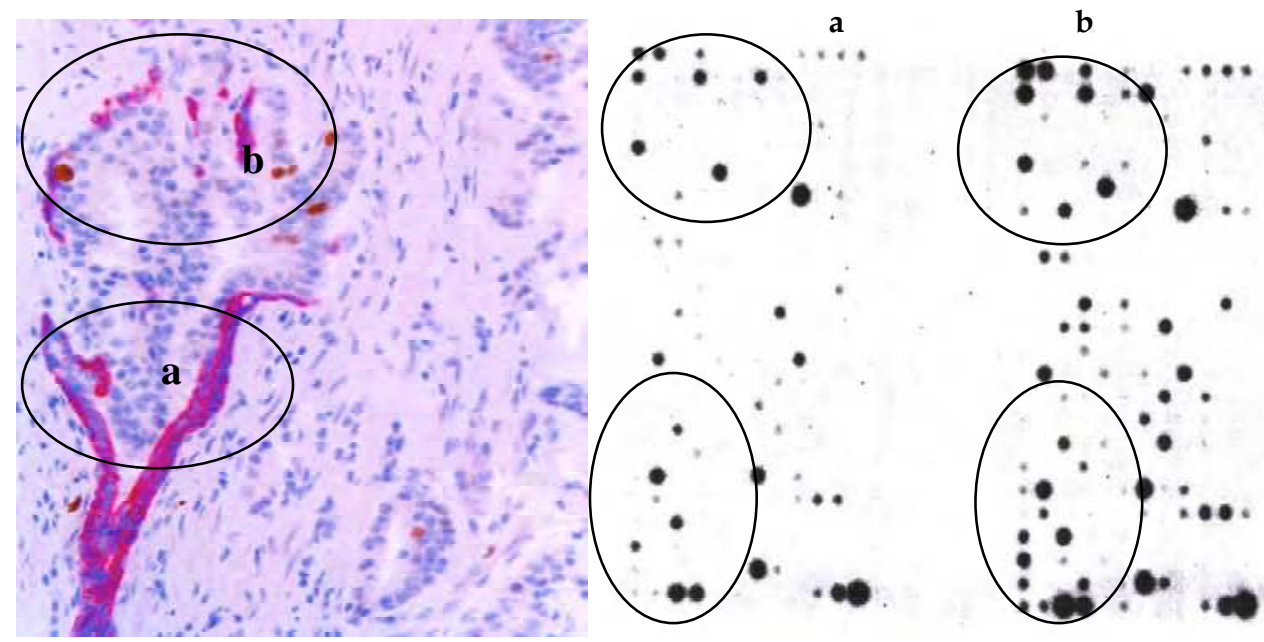

Fig. 15. Different gene expression profiles in cells overlying FBCLD and adjacent counterparts. Cells from these two locations were microdissected from frozen prostate sections, and subjected to RNA extraction, amplification, and gene expression profiling using our published protocols. Circles identify microdissected cells and differentially expressed genes. 


\begin{tabular}{|c|c|c|c|}
\hline$\#$ & Gene name & Potential functions & Fold changes \\
\hline 1 & LIF & Growth factor & 47.37 \\
\hline 2 & MCL1 & Anti-apoptosis & 6.72 \\
\hline 3 & TNFRSF7 & Anti-apoptosis & 7.91 \\
\hline 4 & KIT & Stem cell lineage marker & 5.03 \\
\hline 5 & NCOR2 & Stem cell lineage marker & 5.45 \\
\hline 6 & ENG & Endothelial cell marker & 6.38 \\
\hline 7 & ICAM2 & Endothelial cell marker & 12.12 \\
\hline 8 & KRT17 & Epithelial cell marker & 7.15 \\
\hline 9 & ITGA3 & Cell-matrix adhesion & 5.52 \\
\hline 10 & ITGB3 & Cell-matrix adhesion & 7.14 \\
\hline 11 & CCL2 & Chemokine, cytokine, and receptor & 14.33 \\
\hline 12 & CX3CL1 & Chemokine, cytokine, and receptor & 6.14 \\
\hline 13 & CCR1 & Chemokine, cytokine, and receptor & 5.19 \\
\hline 14 & CXCR4 & Chemokine, cytokine, and receptor & 12.81 \\
\hline 15 & TNFRSF10D & TNF receptor family & 8.20 \\
\hline 16 & TNFRSF12A & TNF receptor family & 5.35 \\
\hline 17 & TNFRSF25 & TNF receptor family & 8.52 \\
\hline 18 & TIMP1 & ECM inhibitor & 5.25 \\
\hline 19 & TIMP3 & ECM inhibitor & 7.87 \\
\hline 20 & MMP-26 & Matrix metalloproteinase & -6.94 \\
\hline 21 & IL10 & Interleukin and receptor & -9.50 \\
\hline 22 & IL12RB2 & Interleukin and receptor & -7.02 \\
\hline 23 & IL6R & Interleukin and receptor & -7.24 \\
\hline
\end{tabular}

Table 6. Differentially expressed genes between cells overlying FBCLD and their adjacent cells

The above alterations were consistently seen in all 17 cases with a high frequency of FBCLD, while were only seen in 1 (9.1\%) of the 11 cases with a low frequency of FBCLD, and in none of the 22 cases with non-disrupted basal cell layers. Together, these findings suggest that the physical and functional status of the basal cell layer significantly impact the biological presentation of associated epithelial cells. These findings also suggest that malignant transformation and stromal invasion could occur in morphologically normal prostate tissues, and that FBCLD may represent a trigger factor for prostate tumor progression and invasion. To our best knowledge, our findings have not been previously reported by others. The most likely reasons are: [1] the enzyme theory has dominated the direction of researches in the field, and the roles of basal cells have been ignored, and [2] these alterations can be seen only by double immunohistochemistry to simultaneously elucidate the basal and epithelial cells. Double immunostaining, however, has not been commonly used in the clinical studies. 


\section{Our hypothesis of tumor invasion}

Based on the above findings, we strongly believe that these normal appearing epithelial structures represent a population of maturation arrested tumor progenitors derived from monoclonal proliferation of genetically altered primitive stem cells at early stages of the prostate morphogenesis probably by trauma, radiation, inflammation, or other factors. These clusters retain the potential for unlimited cell proliferation or multi-lineage differentiation, and could progress directly to invasive lesions through two pathways: (1) In situ malignant transformation, and (2) Progenitor-mediated cell budding. These pathways are likely to contribute to early onset of prostate cancer at young ages, to biologically and clinically more aggressive prostate tumors, and also to highly heterogeneous genetic and biochemical profiles among prostate tumors.

\section{The hypothesized main steps of tumor invasion}

Our hypothesized main steps of invasion for these normal appearing epithelial structures are the followings:

1. At the early stage of prostate morphogenesis, the prostate of these patients exposed to external or internal insults, such as radiation, carcinogens, localized trauma, inflammation, or other factors, which caused permanent damages in the DNA structures of some primitive stem cells.

2. Localized DNA structural damages caused the inactivation of, or defects, in basal cell renewal-related genes, which impaired the basal cell replenishment process to replace the aged or injured basal cells, resulting in a "senesced" basal cell population with significantly reduced functions.

3. Localized DNA structural damages also caused the inactivation of, or defects in, apoptosis-, or cell cycle control related genes in the luminal cell population, which allow these cells to escape from programmed death, to continuously proliferate, and to generate their own vascular structures.

4. Deregulated proliferation in epithelial cells and impaired self-renewal in basal cells resulted in the overstretch and disassociation of the basal cell layer and the basement membrane, which lead to focal breakdown and degeneration of these two structures.

5. The degradation products of degenerated basal cells and the diffusible molecules of the overlying luminal cells function as self-epitopes to attract migration and infiltration of immunoreactive cells or auto-antibodies into the affected sites.

6. The direct physical contact between IRC and degenerated basal cells results in the discharge of the digestive enzymes from IRC, leading to the physical destruction of altered basal cell layers and the local basement membrane, resulting in a focal disruption in these structures.

7. As the epithelium is normally devoid of blood vessels and lymphatic ducts, and the basal cell layer is the sole source of several tumor suppressors, a FBCLD could lead to several focal alterations, including:

a. A loss or reduction of tumor suppressors and the paracrine inhibitory functions, which allow the luminal cells to undergo elevated proliferation [48-52].

b. Alterations in the permeability for oxygen or growth factors, which selectively triggers the exit of stem or progenitor cells from quiescence, and favor proliferation of cells overlying FBCLD [53-55].

c. The exposure of luminal cells to different cytokines, which facilitates vasculogenic mimicry and tumor angiogenesis [56-57]. 
d. The physical contact between luminal and stromal cells augments the expression of stromal MMP, facilitating epithelial-mesenchymal transition (EMT) and cell motility [58-60].

e. The physical contact between luminal and immunoreactive cells directly cause genomic or cellular damages that trigger a cascade reaction of malignant transformation [61-64].

8. These alterations could individually or collectively trigger malignant transformation and stromal invasion through two different, but correlated pathways:

a. In situ malignant transformation, in which the entire basal cell layer undergoes extensive degeneration and multiple focal disruptions (Fig 16) that expose the entire luminal cell population directly to the stroma when all surrounding myoepithelial cells become degenerated. Although these cells might not possess all properties of invasive cancer cells, the changed microenvironment may act as a second "hit" to trigger a cascade reaction of malignant transformation that rapidly alters the genetic and biochemical profiles of these cells.
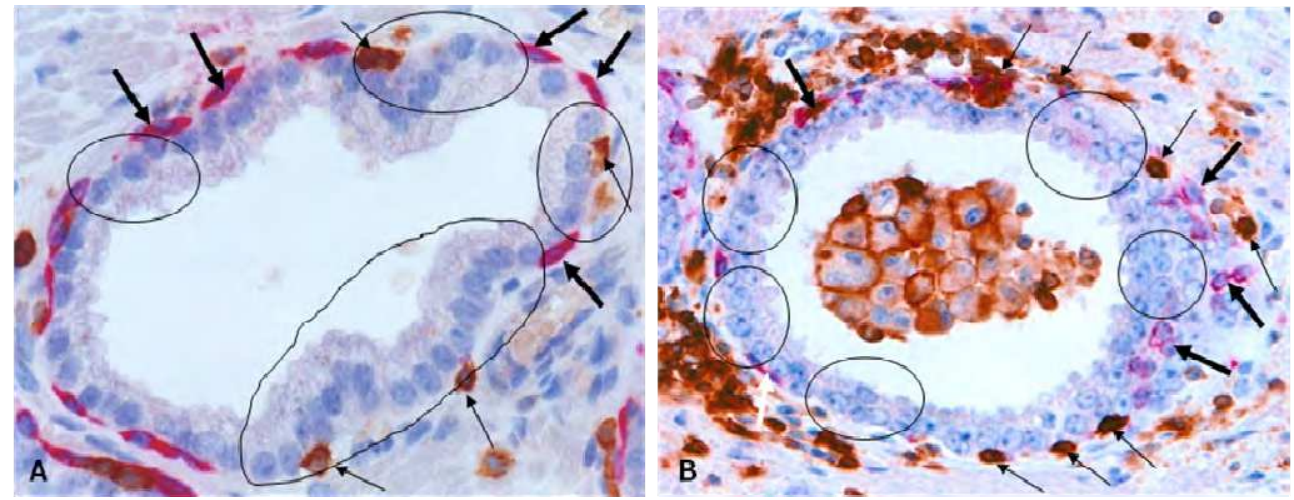

Fig. 16. Hypothesized model of in situ malignant transformation. Human prostate tissues double immunostained for CK34 $\beta$ E12 (red) and LCA (brown). Circles identify FBCLD. Thick arrows identify residual basal cells. Thin arrows identify LCA-positive cells. Note that a vast majority of the epithelial cells are in direct physical contact with the stromal tissue. Also note that most LCA-positive cells are located at or near FBCLD. 300X.

b. Progenitor-mediated cell budding, in which focal basal cell degeneration-induced lymphocyte infiltration causes focal disruptions in the tumor capsules, which selectively favor proliferation and invasion of the overlying tumor stem cells or a biologically more aggressive cell clone. Cells overlying FBCLD gradually increases in volume and form finger-like projections invading into the surrounding stroma (Fig 17).

9. The above events may occur and progress immediately after the external or internal insults, leading to the onset of prostate cancer at young ages. On the other hand, cells of these normal appearing epithelial structures may become maturation-arrested after a few cycles of cells divisions, and remain idle until a new insult [65], representing "bad seeds for bad crops" at later ages. 

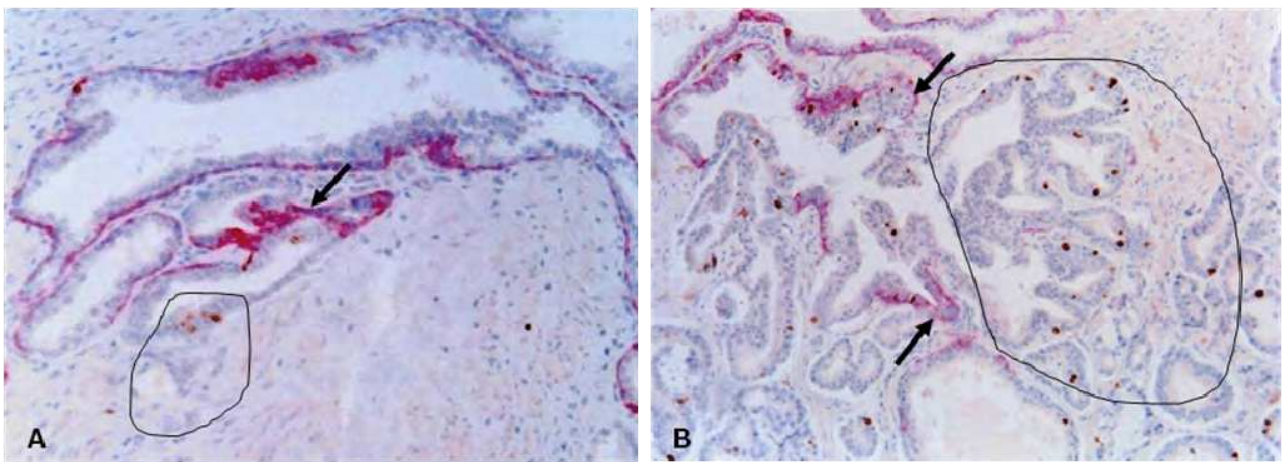

Fig. 17. Hypothesized model of progenitor-mediated cell budding. Human prostate tissues double immunostained for CK34 $\beta$ E12 (red) and proliferation marker Ki-67 (brown). Thick arrows identify residual basal cell layers. Circles identify cell clusters budding from FBCLD. Note that cells budding from FBCLD are morphologically and immunohistochemically similar to adjacent invasive cancer cells, whereas they differ markedly from their adjacent counterpart within the same duct and associated with the residual basal cell layer. 200X.

\section{The main differences between our hypothesis and other theories for tumor invasion}

Based on our own and other findings, we had proposed that prostate tumor invasion is triggered by focal basal cell degeneration-induced aberrant infiltration of lymphocytes that causes focal disruptions in the tumor capsules, which selectively favor monoclonal proliferation and invasion of the overlying tumor stem or progenitor cells [38-39]. Our hypothesis differs from the enzyme theory of tumor invasion in five aspects: (1) the stage of tumor invasion, (2) the cellular origin of the invasive lesions, (3) the significance of the immunoreactive cells, (4) the significance of stromal cells, and (5) the potential approaches for interventions and prevention of tumor invasion. Our studies of breast tumors have obtained similar results and conclusions [66-74]. The new hypothesis presented in our current study is the expansion of our previous hypothesis with the following new points of views:

A. the preservation of large clusters of genetically damaged stem or progenitor cells: Our previous hypothesis proposes that cell clusters overlying FBCLD represent tumor stem or progenitor cells, which undergo a series of immunohistochemical and morphologic changes, and finally transform into invasive lesions [38]. Our current hypothesis suggests that it is also possible that multiple genetically damaged primitive stem or progenitor cells within the same site may generate large duct or acinar clusters that harbor the same genetic defects. These clusters may be formed immediately followed the external or internal insults during the early stage of morphogenesis, and progress rapidly, leading to the early onset of prostate cancer at young ages. These clusters could also become maturation arrested at patients' early ages, while they retain the potential for unlimited proliferation and multi- lineage differentiation, representing "bad seeds for bad crops" at later ages. Our speculation is supported by the results of our gene expression profiling studies, which have detected a over 5-fold higher expression of two stem cell lineage markers, KIT and NCOR2, in cell clusters overlying FBCLD compared to their adjacent counterpart associated with the residual basal cell layers [38] (Fig 15; Table 6). 
B. direct transformation of the entire duct or acinar cluster into invasive lesions: Our previous hypothesis believes that invasive cells are derived exclusively or preferentially from monoclonal proliferation of stem or progenitor cells overlying FBCLD [38]. Our current hypothesis suggests that, in addition to monoclonal proliferation, it is possible that the entire duct or acinar cluster may directly transform into invasive lesions after the disappearance of all surrounding basal cells and the basement membrane.

C. angiogenesis by genetically altered tumor stem cells: Our previous hypothesis proposes that a subset of luminal cell clusters overlying FBCLD are in direct physical continuity with vascular- or lymphatic duct-like structures, which allows them to progress directly to metastasis [38]. Our current hypothesis further suggests that some normal appearing duct or acinar clusters may retain genetically damaged primitive stem cells that could manufacture their own blood vessels or lymphatic ducts, which directly lead to metastasis. Our speculation is consistently supported by our immunohistochemical findings, which show that some of the cell clusters overlying FBCLD appear to directly invade the vascular structures (Fig 11). Our speculation is also supported by the results of our gene expression profiling studies, which have detected a over 6- and 12-fold higher expression of two endothelial cell markers, END and ICAM2, respectively, in cell clusters overlying FBCLD compared to their adjacent counterpart associated with the residual basal cell layers [38] (Fig 15; Table 6).

D. Potential histological origin for cancer of unknown primary site: Cancer of unknown primary site (CUP) is one of the 10 most frequent cancers worldwide and ranks as the $4^{\text {th }}$ most common cause of cancer-related death [22-24]. The development of early, uncommon, systemic metastasis, and resistance to therapy are hallmarks of this clinical entity. Currently, no consensus exists on whether CUP is a group of metastatic tumors with unidentified primaries or a distinct entity with unique genetic/phenotypic aberrations that define it as "primary metastatic disease [22-24]. The normal appearing epithelial structures seen in our current study may represent a potential histological origin for CUP for the following reasons: (1) they are morphologically indistinguishable from clear-cut normal prostate tissues under low magnification on $\mathrm{H} \&$ E stained sections, which allow them to escape from early detection, (2) they retain the property of stem cells and appear to be able to directly invade the stroma and vascular structures, based on our previous [38] and current studies, and (3) they share the same DNA phenotype with invasive prostate cancer based on previous reports [14-17].

\section{The significance of our hypothesis}

During the past 30-years, the cancer research community has been predominantly, if not exclusively, focused on the roles of epithelial cells in prostate tumor progression and invasion. Hundreds and thousands of epithelium- derived molecules have been implicated in the development and progression of prostate cancers. However, only prostate-specific antigen (PSA) has been approved and validated as a clinical diagnostic marker and only growth factor- and androgen receptor-based therapeutic agents have been approved and validated for the clinical trials for prostate cancers. In addition, none of epithelium-derived markers has significant value in predicating the tumor biology or invasiveness, or in identifying the specific individuals with pending prostate cancer, or at higher risk to develop prostate cancer. These findings strongly suggest that the epithelium alone is very unlikely to be sufficient to trigger tumor progression and invasion. 
Our hypothesis, if confirmed, could have several significant implications. Scientifically, it could lead to a new direction to explore novel approaches for early detection, intervention, and prevention of prostate tumor invasion. For example, as non-disrupted basal cell layers have significant inhibitory functions on epithelial cell growth, the development of therapeutic agents to stimulate basal cell growth or regeneration may provide a more effective approach for treatment and prevention of prostate cancer invasion. Clinically, it could potentially bring the following benefits:

1. Better recognition of these clusters may avoid misdiagnosis and facilitate early interventions, which may significantly improve prognosis.

2. Double immunohistochemical staining to assess the physical integrity of the basal cell layer, or an quantitative measurement of basal cell degeneration-related molecules in the blood or biopsies, may facilitate early identification of individuals at greater risk to develop invasive lesions.

3. As genetic alterations not only define the scope and extent of, but also precede, both biochemical and morphological alterations, elucidation of the genetic profile of these normal appearing duct or acinar clusters may lead to the identification of the specific molecules that trigger the initiation of prostate carcinogenesis, progression, and invasion.

4. Currently, the only established approach to monitor prostate tumor progression is repeat biopsy [28-31], which is costly and painful. Our technical approaches of assessing the physical and functional status of the basal cells may be used as a more reliable alternative for repeat biopsy to monitor tumor progression and invasion.

More importantly, our hypothesis may be also applicable to progression and invasion of other epithelium derived tumors.

\section{Acknowledgment}

This study was supported in part by grants DAMD17-01-1-0129, DAMD17-01-1-0130, and PC051308 from the US Congressionally Directed Medical Research Programs, grant BCTR0706983 from The Susan G. Komen Breast Cancer Foundation, grant 05AA from the AFIP/ARP joint research initiative project, grant 2008-02 from the US Military Cancer Institute and Henry Jackson Foundation, and grant 2006CB910505 from the Ministry of Chinese Science and Technology Department.

The tissue blocks or unstained tissue sections used in this study were obtained from our antibody testing service or collaborative research projects with the National Cancer Institute, Toms Jefferson University Medical School, Fairfax Hospital, Howard University Hospital, and Beijing 301 Hospital. The study was conducted in the Armed Forces Institute of Pathology with IRB approved protocols (05-AA and 07-DJ).

\section{References}

[1] Carruba G, Stefano R, Cocciaeliferro L. Intercellular communication and human prostate carcinogenesis. Ann NY Acad Sci. 2002; 963:156-68.

[2] Goldstein NS, Underhiel J, Roszka N, Neill JS. Cytokeratin 34 beta E-12 immunoreactivity in benign prostate acini. Quantitation, pattern assessment, and electron microscopic study. Am J Clin Pathol. 1999; 112:69-74. 
[3] Bonkhoff H, Wernert N, Dhom G, Remberger K. Basement membranes in fetal, adult normal, hyperplastic and neoplastic human prostate. Virchows Arch A Pathol Anat Histopathol. 1991; 418:375-81.

[4] Kosir MA, Wang W, Zukowski KL, Tromp G. Degradation of basement membrane by prostate tumor heparanase. J Surg Res. 1999; 81:42-7.

[5] Bonkhoff H, Remberger K. Morphogenesis of benign prostatic hyperplasia and prostatic carcinoma. Pathology. 1998; 19:12-20.

[6] Bostwick DG. Prospective origins of prostate carcinoma. Prostate intraepithelial neoplasia and atypical adenomatous hyperplasia. Cancer. 1996;78: 330-6.

[7] Haggman MJ, Macoska JA, Wojno KJ, Oesterling JE. The relationship between prostate intraepithelial neoplasia and prostate cancer: critical issues. J Urol. 1997; 58:12-22.

[8] Bonkhoff H, Remberger K. Differentiation pathways and histogenetic aspects of normal and abnormal prostatic growth: a stem cell model. Prostate. 1996;28: 98-106.

[9] Barsky SH, Siegal GP, Jannotta F, Liotta LA. Loss of basement membrane components by invasive tumors but not by the benign counterparts. Lab Invest. 1983; 49:140-7.

[10] Goldfarb RH, Liotta LA. Proteolytic enzymes in cancer invasion and metastasis. Semin Thromb Hemost. 1986; 12: 294-307.

[11] Gardner WA, Culberson DE. Atrophy and proliferation in the young adult Prostate. J. Urol. 1987; 137(1): 53-6.

[12] Gardner WA. Hypothesis: Pediatric Origins of Prostate Cancer. Hum Path 1995; 26:1291-1292.

[13] Bennett BD, Gardner WA. Embryonal hyperplasia of the prostate. Prostate. 1985; 3 (7): 411-7.

[14] Malins DC, Polissar NL, Su Y, Gardner HS, Gunselman SJ. A new structural analysis of DNA using statistical models of infrared sepctra. Nat Med. 1997; 3: 927-30.

[15] Malins DC, Johnson PM, Barker EA, et al. Cancer-related changes in prostate DNA as men age and early identification of metastasis in prostate tumors. Proc Natl Acad Sci USA. 2003; 100: 5401-6.

[16] Malins DC, Anderson KM, Gilman NK, et al. Development of a cancer DNA phenotype prior to tumor formation. Proc Natl Acad Sci Sci USA. 2004; 101:10721-5.

[17] Malins DC, Gilman NK, Green VM, et al. A DNA phenotype in healthy prostates, conserved in tumors and adjacent normal cells, implies a relationship to carcinogenesis. Proc Natl Acad Sci USA. 2005; 102: 19093-6.

[18] Ashida S, Nakagawa H, Katagiri T, Furihata M, Liizumi M, Anazawa Y, et al. Molecular features of the transition from prostate intraepithelial neoplasia (PIN) to prostate cancer: genome-wide gene-expression profiles of prostate cancers and PINs. Cancer Res. 2004; 64:5963-72.

[19] Dawkins HJ, Sellner LN, Turbett GR, Thompson CA, Redmond SL, MeNeal JE, Cohen RJ. Distinction between intraductal carcinoma of the prostate (IDC-P), high-grade dysplasia (PIN), and invasive prostatic adecarcinoma, using molecular markers of cancer progression. Prostate. 2000; 44:265-70.

[20] Harvei S, Skijorten FJ, Robsahm TE, Berner A, Tretli S. Is prostaticibtraepithelial neoplasi in the transitio/central zone a true presursor of cancer? A long-tern retrospectivestudy in Norway. Br J Cancer. 1998; 78:46-9. 
[21] Goeman L, Joniau S, Ponette D, Van der Aa F, Roskams T, Oyen R, Van Poppel H. Is low-grade prostatic intraepithelial neoplasia a risk factor for cancer. Prostate Cancer Prostatic Dis. 2003; 6:305-10.

[22] Pentheroudakis, G, Briasoulis, E, Pavlidis, N. Cancer of unknown primary site: missing primary or missing biology? Oncologist 2007; 12(4):418-425.

[23] Carlson HR. Carcinoma of unknown primary: searching for the origin of metastasis. JAAPA. 2009; 22(8): 18-21.

[24] Pentheroudakis, G, Pavlidis, N. Probing the unknown in cancer of unknown primary: which way is the right way? Ann Oncol. 2010, Jan 20 [Epub ahead of print].

[25] Parker SL, Tong T, Bolders S, Wingo PA. Cancer statistics. Cancer J Clin. 1997;47: 5-27.

[26] Bostwick DG. Prostatic intraepithelial neoplasia is a risk factor for cancer. Semin Urol Oncol. 1999; 17:187-9.

[27] Bostwick DG, Qian J, Frankel K. The incidence of high grade prostatic intraepithelial neoplasia in needle biopsies. J Urol. 1985; 154: 1791-4.

[28] Mostofi FK, Sesterhenn IA, Davis CJ Jr. Prostatic intraepithelial neoplasia (PIN): morphological clinical significance. Prostate Suppl. 1992; 4:71-7.

[29] Kasahara Y, Tsukada Y. New insights and future advances in cancer diagnostics: Limitations of conventional tumor markers. In: Nakarnura RM, Grody WW, Wu JT, Nagle RB, editors. Cancer Diagnostics: Current and future trends. Totowa, NJ: Humanna Press; 2004.

[30] Joniau S, Goeman L, Pennings J, Van Poppel H. Prostatic intraepithelial neoplasia (PIN): importance and clinical managment. Eur Urol. 2005; 48:379-85.

[31] Haggman MJ, Adolfsson J, Khoury S, Montie JE, Norlen J. Clinical managment of premalignant lesions of the prostate. WHO Collaborative Project and Consensus Conference on Public Health and Clinical Significance of Premalignant Alterations in the Genitourinary Tract. Scand J Urol Nephol Suppl. 2000; 205:44-9.

[32] Signoretti S, Waltregny D, Dilks J, et al. p63 is a prostate basal cell marker and is required for prostate development. Am J Pathol. 2000; 157:1769-75.

[33] Kurita T, Medina RT, Mills AA, Cunha GR. Role of p63 and basal cells in prostate. Development. 2004; 131: 4955-64.

[34] Zou Z, Zhang W, Young D, et al. Maspin expression profile in human prostate cancer $(\mathrm{caP})$ and in vitro induction of maspin expression by androgen ablation. Clin Cancer Res. 2002; 8(5):1172-7.

[35] Cher ML, Biliran HR jr, Bhangat S, et al. Maspin expression inhibits osteolysis, tumor growth, and angiogenesis in animal model of prostate cancer bone metastasis. Proc Natl Acad Sci USA. 2003; 100(13):7847-52.

[36] Man YG, Shen T, Zhao YG, Sang QXA. Focal prostate basal cell layer disruptions and leukocyte infiltration are correlated events: A potential mechanism for basal cell layer degradations and tumor invasion. Cancer Detect Prev. 2005; 29:161-9.

[37] Man YG, Zhao CQ, Wang J, XL Chen. A subset of prostate basal cells lacks corresponding phenotypic markers. Pathology-Research \& Practice. 2006; 202 (9): 651-62.

[38] Man YG, Gardner WA. Focal degeneration of basal cells and the resultant autoimmunoreactions: a novel mechanism for prostate tumor progression and invasion. Medical Hypoth. 2008; 70: 387-408. 
[39] Man YG, Gardner WA. Bad seeds produce bad crops: a single step-process of prostate carcinogenesis and progression. Int J Biol Scien. 2008; 4: 246-58.

[40] Liu AJ, Wei LX, Gardner WA, Man YG. Correlated alterations in prostate basal cell layer and basement membrane. Int J Biol Sci. 2009; 5: 276-85.

[41] Man YG. A seemingly most effective target for early detection and intervention of prostate tumor Invasion. J Cancer. 2010; 1: 63-9.

[42] Man YG, Harley R, Mason J, Gardner WA. Contributions of leukocytes to tumor invasion and metastasis: the "piggy-back" hypothesis. Cancer Epidem 2010; 34(1): 3-6.

[43] Man YG, Mason J, Harley R, Kim YH, Zhu KM, Gardner WA. Leukocyte-facilitated tumor dissemination: a novel model for tumor cell dissociation and metastasis. J Cell Biochem. 2011 Feb 10. doi: 10.1002/jcb. 23035. [Epub ahead of print]

[44] Man YG, Fu SW, Liu AJ, Stojadinovic A, Izadjoo M, Chen L, Gardner WA. Aberrant expression of chromogranin A, miR-146a, and miR-146b-5p in prostate structures with focally disrupted basal cell layers: an early sign of invasion and hormonerefractory cancer? Submitted.

[45] Berruti A, Mosca A, Porpiglia F, Bollito E, Tucci M, Vana F, Cracco C, Torta M, Russo L, Cappia S, Saini A, Angeli A, Papotti M, Scarpa RM, Dogliotti L. Chromogranin A expression in patients with hormone negative prostate cancer predicts the development of hormone refractory disease. J Urol. 2007; 178(3 Pt1): 838-43.

[46] Grimaldi F, Valotto C, Barbina G, Visentini D, Trianni A, Cerruto MA, Zattoni F. The possible role of chromogranin $\mathrm{A}$ as a prognostic factor in organ-confined prostate cancer. Int J Biol Markers. 2006:21(4): 229-34.

[47] Berruti A, Mosca A, Tucci M, Terrone C, Torta M, Tarabuzzi R, Russo L, Cracco C, Bollito E, Scarpa RM, Angeli A, Dogliotti L. Independent prognostic role of circulating chromogranin A in prostate cancer patients with hormone-refractory disease. Endocr Relat Cancer. 2005; 12(1):109-17.

[48] Verona EV, Elkahloum AG, Yang J, Bandyopadhyay A, Yeh IT, Sun LZ. Transforming growth factor-beta signaling in prostate stromal cells supports prostate carcinoma growth by up-regulating stromal genes related to tissue remodeling. Cancer Res. 2007; 67(12):5737-46.

[49] Zhou W, Grandis JR, Wells A/ STAT3 is required but not sufficient for EGF receptormediated migration and invasion of human prostate carcinoma cell lines. Br J Cancer. 2006; 95(2):164-71.

[50] Chung IW, Baseman A, Assikis V, Zhau HE. Molecular insights into prostate cancer progression: the missing link of tumor microenvironment. J Urol. 2005;173(1):10-20.

[51] Boulikas T. Control of DNA replication by protein phosphorylation. Anticancer Res. 1994; 14: 2465-72.

[52] Boulikas T. Phosphorylation of transcription factors and control of the cell cycle. Crit Rev Eukaryot Gene Expr. 1995; 5: 1-77.

[53] Chakravarthy MV, Spangenhurg EE, Booth FW. Culture in low levels of oxygen enhances in vitro proliferation potential of satellite cells from old skeletal muscles. Cell Mol Life Sci. 2001; 58: 1150-8.

[54] Csete M, Walikonis J, Slawny N, et al. Oxygen-mediated regulation of skeletal muscle satellite cell proliferation and adipogrnesis in culture. J Cell Physical. 2001; 189:18996. 
[55] Studer L, Csete M, Lee SH. Enhanced proliferation, survival, and dopaminergic differentiation of CNS precursors in lowed pxygen. J Neurosci. 2000; 20: 7377-83.

[56] Klos KS, Wyszomierski SL, Sun M et al. c-erbB2 increases vascular endothelial growth factor protein synthesis via activation of mammalian target of rapamycin/p70S6K leading to increased angiogenesis and spontaneous metastasis of human breast cancer cells. Cancer Res. 2006; 66(4): 2028-37.

[57] Hendrix MJ, Seftor EA, Hess AR, Seftor RE. Vasculogenic mimicry and tumor-cell plasticity: lessons from melanoma. Nat Rev Cancer. 2003; 3(6): 411-21.

[58] Kang Y, Massague J. Epithelial-mesenchymal transition: twist in development and metastasis. Cell. 2004; 118: 277-9.

[59] Sato T, Sakai T, Noguchi Y, Takita M, Hirakawa S, Ito A. Tumor-stromal cell contact promotes invasion of human uterine cervical carcinoma cells by augmenting the expression and activation of stromal matrix metalloproteinases. Gynecol Oncol. 2004; 92: 47-56.

[60] Strizzi L, Bianco C, Normanno N. Epithelial mesenchymal transition is a characteristic of hyperplasias and tumors in mammary gland from MMTV-Criptol-1 transgenic mice. J Cell Physiol. 2004; 201:266-76.

[61] Smith, CJ, Gardner WA., Jr. Inflammation - Proliferation: Possible Relationships in the Prostate. In: D Coffey, N Bruchovsky, W Gardner, M Resnick, J Karr (Eds.) Current concepts in prostate cancer. Alan R. Liss, NY, NY 1987.

[62] Nelson G, Culberson DE, Gardner WA. Intraprostatic Spermatozoa. Hum Path. 1988; 19(1):119-20.

[63] Peek RM Jr, Mohla S, DuBois RN. Inflammation in the genesis and perpetuation of cancer: summary and recommendations from a national cancer institute-sponsored meeting. Cancer Res. 2005; 65: 8583-6.

[64] MacLennan GT, Eisenberg R, Fleshman RL et al. The influence of chronic inflammation in prostatic carcinogenesis: a 5-year follow-up study. J Urol. 2006; 176: 1012-6.

[65] Sell S, Pierce GB. Maturation arrest of stem cell differentiation is a common pathway for the cellular origin of teratocarcinomas and epithelial cancers. Lab Invest. 1994; 70, 6-22.

[66] Man YG, Tai L, Barner R, Vang R, Saenger JS, Shekitka KM, et al. Cell clusters overlying focally disrupted mammary myoepithelial cell layers and adjacent cells within the same duct display different immunohistochemical and genetic features: implications for tumor progression and invasion. Breast Cancer Res. 2003; 5: R23141.

[67] Man YG, Sang QXA. The significance of focal myoepitehlial cell layer disruptions in breast tumor invasion: a paradigm shift from the "protease-centered" hypothesis. Exp Cell Res. 2004; 301: 103-18.

[68] Yousefi M, Mattu R, Gao C, Man YG. Mammary ducts with and without focal myoepithelial cell layer disruptions show a different frequency of white blood cell infiltration and growth pattern: Implications for tumor progression and invasion. AIMM. 2005; 13:30-7.

[69] Man YG, Zhang Y, Shen T, Vinh TN, Zeng X, Tauler J, Mulshine JL, Strauss BL. cDNA expression profiling identifies elevated expressions of tumor progression and invasion related genes in cell clusters of in situ breast tumors. Breast Cancer Res Treat. 2005; 89:199-208. 
[70] Man YG, Nieburgs HE. A subset of cell clusters with malignant features in morphologically normal and hyperplastic breast tissues. Cancer Detect Prev. 2006; 30 (3):239-47.

[71] Man YG. Focal degeneration of aged or injured myoepithelial cells and the resultant auto-immunoreactions are trigger factors for breast tumor invasion. Medical Hypotheses. 2007; 69(6): 1340-57.

[72] Man YG. Bad seeds produce bad crops: a single-stage process of breast carcinogenesis. Bioscience Hypotheses. 2008; 1:147-155.

[73] Man YG. Tumor cell budding from focally disrupted tumor capsules: a common pathway for all breast cancer subtype derived invasion? Journal of Cancer 2010, 1 : 27-31.

[74] Man YG, Grinkemeyer M, Izadjoo M, Stojadinovic A. Malignant transformation and stromal invasion from normal or hyperplastic tissues: true or false? J Cancer. 2011; 2: $386-400$. 


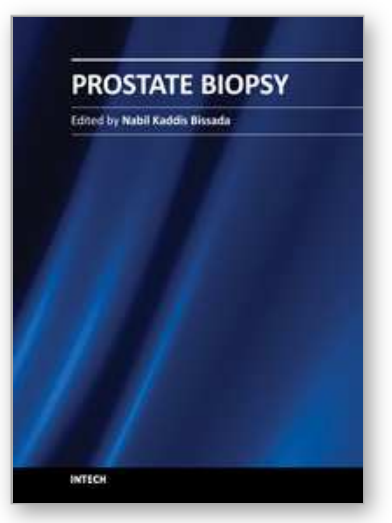

\author{
Prostate Biopsy \\ Edited by Dr. Nabil K. Bissada
}

ISBN 978-953-307-702-4

Hard cover, 134 pages

Publisher InTech

Published online 02, December, 2011

Published in print edition December, 2011

Prostate Biopsy represents the standard procedure for diagnosing Prostate Cancer. This procedure can be performed transrectally, through perineum or occasionally through the urethra. Although the procedures of Prostate Biopsy are covered in numerous publications, there is still a need for gathering different aspects and methods in one source. Hopefully, this book will help physicians in their effort to provide the best treatment for their patients.

\title{
How to reference
}

In order to correctly reference this scholarly work, feel free to copy and paste the following:

Yan-gao Man (2011). Malignant Transformation and Stromal Invasion from Normal Appearing Prostate Tissues: True or False?, Prostate Biopsy, Dr. Nabil K. Bissada (Ed.), ISBN: 978-953-307-702-4, InTech, Available from: http://www.intechopen.com/books/prostate-biopsy/malignant-transformation-and-stromalinvasion-from-normal-appearing-prostate-tissues-true-or-false-

\section{INTECH}

open science | open minds

\section{InTech Europe}

University Campus STeP Ri

Slavka Krautzeka 83/A

51000 Rijeka, Croatia

Phone: +385 (51) 770447

Fax: +385 (51) 686166

www.intechopen.com

\section{InTech China}

Unit 405, Office Block, Hotel Equatorial Shanghai

No.65, Yan An Road (West), Shanghai, 200040, China

中国上海市延安西路65号上海国际贵都大饭店办公楼405单元

Phone: +86-21-62489820

Fax: +86-21-62489821 
(C) 2011 The Author(s). Licensee IntechOpen. This is an open access article distributed under the terms of the Creative Commons Attribution 3.0 License, which permits unrestricted use, distribution, and reproduction in any medium, provided the original work is properly cited. 